\title{
REFLECTION
}

\section{When "Patient-Centered" is Not Enough: A Call for Community-Centered Medicine}

\author{
Juliana E. Morris, MD, EdM \\ Department of Family and Community \\ Medicine, University of California, San \\ Francisco, California
}

\begin{abstract}
Before entering medicine, I was inspired by community organizing as a model for driving social change and improving public health. As a clinician, I remain inspired by this approach; however, I find that it has been more challenging to integrate into my day-to-day work than I expected. In this essay, I describe my journey from community organizer to primary care clinician and reflect on the lessons I've learned about the value of community organizing and ways that it can be incorporated into clinical practice. Ultimately, I propose a model for how clinicians and health centers can proactively partner with community organizing groups and facilitate referrals to help patients directly engage in transforming the root causes of their health challenges. This model shifts the focus from the patient as an individual agent of change to the community, and offers important lessons to clinicians interested in community health equity.
\end{abstract}

Ann Fam Med 2019;17:82-84. https://doi.org/10.1370/afm.2335.

was elbow-deep in my Step One boards review book when I received the call.

"The state senate just added a bunch of anti-immigrant amendments to the budget," Roberto told me, "They want to slash our access to health care, employment, decent housing... will you come down to the State House right now? We have to fight this."

I looked down at the recently highlighted paragraphs on amino acid metabolism. "I can study this later tonight," I thought. I threw on my t-shirt with the logo of our youth-led immigrant rights group and headed out the door.

Dozens of people had already gathered at the State House by the time I arrived, filling the wide sidewalk in front of the iron-gated perimeter. I made my way toward the front of the crowd and greeted Roberto and other friends, who were putting the finishing touches on the rally chant sheets and signs. "How's school?" Roberto asked, "Are you ready yet to be the doctor for the movement?" I laughed, "Not quite, barely finished second year." He smiled and handed me a sign, "Don't Cut Our Futures." I held it up proudly and joined the ranks of the chanting crowd.

A few speakers later, my friend Daniela was up at the podium, clasping the microphone with both hands. Her long brown hair blew in the wind and she squinted into the sunlight as she began, "When I was 12 years old, my family and I arrived to the United States from Chile. I started going to school, learning English. I worked hard. But then, it hit me. I mean, I was about to graduate from high school and after putting in all that work, I found out I didn't have the possibility of going to college, or pursuing my dream job." I sucked in air and felt my chest and jaw tighten. Even though I had heard her story dozens of times, each time it brought me back to when she had first confided in me months before in the back of a dim coffee shop; to that moment when, with my faced flushed with indignation, I realized that, while I was already in graduate school, Daniela, just 2 years
Juliana E. Morris, MD, EdM Department of Family and Community Medicine, University of California 1001 Potrero Ave, Ward 83 San Francisco, CA 94110 juliana.morris@ucsf.edu 
younger than me, had to fight for years just to make it to college.

Everything was off limits because I was undocumented," she continued, "I became severely depressed, and my sugars-I have type 1 diabetes-were getting out of control. So one day, I was at my doctor's office, telling her about these struggles for probably the hundredth time. She seemed almost as frustrated as I was. We had tried every pill, therapy, dose adjustment ${ }_{\text {; }}$ we were pretty much out of options. Finally, in a moment of desperation, she opened a Google search page and typed in, 'undocumented youth organization.' A few weeks later, I went to my first meeting.

As Daniela described her early days in youth organizing, I reflected on my own journey into immigrant rights work: the stories of my grandfather arriving at Ellis Island as a teenager, the marches and protests in my community against hate crimes and harmful antiimmigrant bills, and the years I volunteered in migrant shelters and free clinics. I eventually decided to pursue a career in medicine, to serve and continue learning from and working in solidarity with immigrant communities. I joined the youth immigrant rights group after relocating for medical school, to stay connected to that mission.

"I found community in our organizing work," Daniela continued,

I met people who were also undocumented, going through the same struggles as I was, and didn't feel alone anymore. I got connected to other people in my community who were willing to put their privilege on the line to fight for our rights. Together, we have been able to fight for access to education and win other changes to help our community. Through a combination of gaining more opportunities and feeling more supported, my health has gotten a lot better in the process.

She paused, and I took a deep breath, thinking about the impact of Daniela's doctor's intervention. This journey had helped Daniela so much, and the rest of us had gained an amazing community leader in the process.

Daniela finished off her testimonial with her fist in the air, and the crowd erupted in applause. I placed my sign in the crook of my arm and clapped loudly. Daniela scanned the crowd, caught my eye for the first time that day, and smiled. I smiled back and nodded, knowing that we were in this fight together.

Four years later, across the country in my first year of family medicine residency, I donned my white coat and stepped into the exam room at my afternoon clinic. My first patient of the day was Martin, a young father in his late 20s whom I had just started treating for irritable bowel syndrome. That day, he confided his mounting anxiety in the face of a recent Immigration and Customs Enforcement raid near his workplace. He was undocumented, had 2 citizen children, and was terrified that deportation would tear his family apart. The month before, I had referred him to a pro bono lawyer, but that had yielded no results. Now, I thought about encouraging him to join one of the local immigrant rights committees, as Daniela's doctor had done, but I hesitated. I knew Martin worked 2 jobs to support his family; his long workdays and resulting lack of sleep were already contributing to his stress. I was worried it would seem like I was asking too much, or that he would feel it wasn't my place to make this type of suggestion. And, frankly, I wasn't sure exactly how to do it. In my medical training, I had seen plenty of my attending physicians make referrals to serviceoriented organizations and had been taught how to do so myself, but I had never seen anyone directly refer to a community organizing committee.

And yet, from my experience as an organizer, I knew that Martin's participation in movement work, even in small ways, could make a real difference in helping him combat his anxiety and change the material conditions of his life. I also knew that, like Daniela, he had skills and expertise that could be harnessed to transform his community.

Of course, I couldn't know for sure whether community organizing would be the best fit for him as an individual. But, just like when I recommend a home exercise regimen or deep breathing exercises, because I believed this intervention could make a difference in his health, it was my job to provide him with the information and a listening ear to help him make his own decision. I hesitated that day when Martin first opened up to me; but at our next visit I asked him more about his interests and group affiliations and provided information on several community organizing groups for him to consider.

This is just one example. There are many ways that a community organizing perspective can be integrated into primary care clinics. Clinicians can investigate and make referrals themselves, as I did, or provide warm handoffs to local community organizers. Clinics can hire their own staff community organizers, who discuss issues with patients in the waiting areas or exam rooms and connect them to local groups. Organizational policies can be put in place to maintain active connections with organizing groups and commit to mobilizing clinic resources to support local organizing initiatives.

In achieving this integration, we as clinicians can expand our practice of patient-centered care to include an additional focus on community-centered medicine. This approach helps us think outside the clinic walls and to learn from community-driven solutions to prob- 
lems, which can help us be more effective clinically and also ward off burnout. It honors the incredible power that our patients possess to transform their own health through leadership and collective action. And it clarifies the roles we all can play in improving community health, after all, health care workers are also community members, striving along with our neighbors for a healthier future.

In family medicine, we are well equipped to take on a call for community-centered medicine. Approaches grounded in community are fundamental to the ethos of our profession. Thus far, however, only scattered clinics have implemented dedicated community organizing initiatives and referral systems. To more robustly and widely implement these programs, and fully take advantage of the benefits they can offer patients, clinicians, and health systems will take commitment and vision. We need clinics where offering and supporting community organizing resources is streamlined, not an awkward afterthought; where patients like Daniela and Martin will be supported and treated with loving care, while also being recognized for their strengths and expertise. In building up the practice of community-centered medicine, we can move closer toward realizing this vision, and nurturing improved health for all as "doctors for the movement."

To read or post commentaries in response to this article, see it online at http://www.AnnFamMed.org/content/17/1/82.

Key words: community participation; social change; emigrants and immigrants; health equity; social determinants of health; community health services

Submitted August 6, 2018; submitted, revised, October 3, 2018; accepted October 18, 2018.

Acknowledgment: Thank you to Daniela Bravo for her role in inspiring these reflections and her thoughtful review of the manuscript.

\section{CHANGE-OF-ADDRESS FORM \\ FAMNILY MEDICINE}

Please complete this form and mail to the following address or fax to Annals Circulation at 913-906-6080:

Annals of Family Medicine, Circulation Department, 11400 Tomahawk Creek Pkwy, Leawood, KS 66211-2680

Check if member of sponsoring organization:

$$
\begin{aligned}
& \square \text { AAFP } \square \text { ABFM } \square \text { STFM } \square \text { ADFM } \\
& \square \text { AFMRD } \square \text { NAPCRG } \square \text { CFPC }
\end{aligned}
$$

ID number from label on your journal cover

OLD Information (Please print.)

\begin{tabular}{ll}
\hline Name & \\
\hline Company (if applicable) & \\
\hline Address (Street plus Apt or Ste) & State \\
\hline City & Postal Code (9-digit ZIP for US) \\
\hline Country & Fax \\
\hline Telephone & \\
\hline E-Mail
\end{tabular}

NEW Information (Please print.)

\begin{tabular}{ll}
\hline Name \\
\hline Company (if applicable) & \\
\hline Address (Street plus Apt or Ste) & \\
\hline City & Postal Code (9-digit ZIP for US) \\
\hline Country & \\
\hline Telephone & \\
\hline E-Mail & \\
\hline
\end{tabular}

